\title{
PENGARUH FREKUENSI PENGGORENGAN TERHADAP PENINGKATAN PEROKSIDA MINYAK GORENG CURAH DAN FORTIFIKASI VITAMIN A
}

\author{
Wahyu Siswanto, Surahma Asti Mulasari \\ Fakultas Kesehatan Masyarakat, Universitas Ahmad Dahlan, Yogyakarta, Indonesia \\ Email: rahmasti_fkmuad@yahoo.com
}

\begin{abstract}
Background: Palm oil industry in Indonesia is divided into two there are cooking oil and branded cooking oil. Currently there area variety of branded cooking oil advantages, one of which is the fortification of vitamin A. Based on previous research it is known that $90 \%$ of house holds do frying as much as 4-8 times per day. Cooking oil used repeatedly can oxidize (react with air) so increasing levels of peroxide. Consumption of cooking oil containing high peroxide can cause health problems such as gastrointestinal irritation, diarrhea, and cancer. This study aims to determine the effect of the increase in the frequency of frying peroxide on cooking oil and cooking oil fortification of vitamin A was used.

Method: This was experimental research with quasy experimental design. The research object in this study was cooking oil and vitamin A fortification of cooking oil used to fry out. Peroxide measurements made on a grill to 0, 1, 2, 3, 4 with three repetitions in each cooking oil.

Result: On average the lowest peroxide contained in the zero frying process was equal to 5.27 $\mathrm{MekO}_{2} / \mathrm{Kg}$ (cooking oil) and $0.83 \mathrm{MekO}_{2} / \mathrm{Kg}$ (vitamin A fortification of cooking oil) and continued to increase until the fourth frying at $18.86 \mathrm{MekO}_{2} / \mathrm{Kg}$ (cooking oil) and $17.48 \mathrm{MekO}_{2} / \mathrm{Kg}$ (vitamin $A$ fortification of cooking oil). Cooking oil used repeatedly peroxide can affect the increase in cooking oil ( $P$ value 0.010$)$ and vitamin $A$ fortification of cooking oil ( $P$ value 0.012$)$ and no differences peroxide between cooking oil and vitamin $A$ fortification oil ( $p$ value 0.065 ). Conclusion: There were the influence of the frying process to the increased frequency of peroxide value on cooking oil. There were the effect of the increase in the frequency of peroxide value frying cooking oil fortification on vitamin $A$. There was no difference between the peroxide cooking oil and vitamin A fortification of cooking oil.
\end{abstract}

Keywords: cooking oil, difference, fortification, peroxide value, frying

\begin{abstract}
Abstrak
Latar Belakang: Industri minyak goreng sawit di Indonesia terbagi menjadi dua yaitu minyak goreng curah dan minyak goreng bermerek. Saat ini terdapat bermacam-macam keunggulan minyak goreng bermerek, salah satunya adalah minyak goreng fortifikasi vitamin $A$. Berdasarkan penelitian sebelumnya diketahui bahwa $90 \%$ rumah tangga melakukan penggorengan sebanyak 4-8 kali per hari. Minyak goreng yang digunakan berulang-ulang dapat mengalami oksidasi (bereaksi dengan udara) sehingga meningkatkan kadar bilangan peroksida. Konsumsi minyak goreng yang mengandung bilangan peroksida yang tinggi dapat menyebabkan gangguan kesehatan seperti iritasi saluran pencernaan, diare, dan kanker. Penelitian ini bertujuan untuk mengetahui pengaruh frekuensi penggorengan terhadap peningkatan bilangan peroksida pada minyak goreng curah dan minyak goreng fortifikasi vitamin A.
\end{abstract}

Metode: Jenis penelitian yang digunakan adalah experimental research dengan rancangan quasi experimental. Objek penelitian pada penelitian ini adalah minyak goreng curah dan minyak goreng fortifikasi vitamin A yang digunakan untuk menggoreng tahu. Pengukuran bilangan peroksida dilakukan pada penggorengan ke 0, 1, 2, 3, 4 dengan tiga kali pengulangan pada masing-masing minyak goreng.

Hasil: Rata-rata bilangan peroksida terendah terdapat pada penggorengan ke nol yaitu sebesar $5,27 \mathrm{Mek} \mathrm{O}_{2} / \mathrm{Kg}$ (minyak goreng curah) dan 0,83 Mek $\mathrm{O}_{2} / \mathrm{Kg}$ (minyak goreng fortifikasi vitamin

Pengaruh Frekuensi Penggorengan terhadap Peningkatan Peroksida ..... (Wahyu Siswanto) 
A) dan terus meningkat hingga penggorengan keempat sebesar 18,86 Mek $\mathrm{O}_{2} / \mathrm{Kg}$ (minyak goreng curah) dan 17,48 $\mathrm{Mek}_{2} / \mathrm{Kg}$ (minyak goreng fortifikasi vitamin A). Minyak goreng yang digunakan berulang-ulang dapat mempengaruhi peningkatan bilangan peroksida pada minyak goreng curah ( $P$ value 0,010$)$ dan tidak ada perbedaan bilangan peroksida pada minyak goreng curah dengan minyak goreng fortikasi vitamin $A$ ( $p$ value 0,065$)$.

Kesimpulan: Ada pengaruh frekuensi penggorengan terhadap peningkatan bilangan peroksida pada minyak goreng curah. Ada pengaruh frekuensi penggorengan terhadap peningkatan bilangan peroksida pada minyak goreng fortifikasi vitamin $\mathrm{A}$. Tidak ada perbedaan bilangan peroksida antara minyak goreng curah dan minyak goreng fortifikasi vitamin $A$

Kata Kunci: minyak goreng, perbedaan, fortifikasi, bilangan peroksida, penggorengan

\section{Pendahuluan}

Minyak goreng adalah salah satu produk jadi primer yang dihasilkan dari buah kelapa sawit. Produksi industri minyak kelapa sawit dunia dan Indonesia mengalami peningkatan. ${ }^{1}$ Industri minyak goreng kelapa sawit di Indonesia terbagi menjadi dua, yaitu minyak goreng curah dan minyak goreng bermerek. Minyak goreng curah adalah minyak goreng yang dijual ke pasar tanpa menggunakan merek dan label produk, biasanya ditempatkan di jerigen besar atau drum, kemudian dijual literan kepada konsumen. sedangkan minyak goreng bermerek adalah minyak goreng yang ditawarkan ke pasar dengan menggunakan kemasan khusus (baik botol, jerigen, atau plastik) yang mempunyai merek perusahaan produsen serta label mengenai segala sesuatu tentang produk. ${ }^{2}$

Berdasarkan riset, minyak goreng curah mendominasi pasar dengan meraup pangsa sebesar $30 \%$ dari total pangsa pasar minyak goreng, sisanya dikuasai oleh minyak goreng bermerek. ${ }^{3}$ Saat ini terdapat setidaknya 24 merek minyak goreng dan itu belum termasuk merek-merek minyak goreng yang beredar lokal di daerah tertentu. ${ }^{4}$ Minyak goreng bermerek berlomba-lomba mengklaim bahwa produknya yang terbaik dengan menonjolkan keunggulan masing-masing salah satunya dengan fortifikasi vitamin $A^{5}$ Minyak goreng fortifikasi vitamin $A$ pada minyak goreng merupakan program pemerintah yang bertujuan untuk menurunkan jumlah orang, terutama anak, yang kekurangan vitamin $A .{ }^{6}$

Pada tahun 1970-an, pemerintah memberikan suplemen vitamin A berupa kapsul ke masyakarat dengan kandungan 200.000 IU per 6 bulan. Hasilnya cukup memuaskan namun, program suplementasi sewaktu-waktu dapat berhenti, maka fortifikasi menjadi pilihan terbaik untuk menutupi kekurangan yang ada melalui pemberian vitamin A pada pangan. ${ }^{7}$ Berdasarkan penelitian ${ }^{8}$ diketahui bahwa $90 \%$ rumah tangga melakukan penggorengan sebanyak 4-8 kali perhari. Penggorengan yang dilakukan secara berulang dapat menyebabkan minyak menjadi tengik dan mempengaruhi kenaikan bilangan peroksida. Ketengikan merupakan salah satu tanda kerusakan pada minyak goreng. ${ }^{9}$ Bilangan peroksida merupakan salah satu indikator yang digunakan untuk mengetahui seberapa besar tingkat kerusakan suatu minyak goreng. ${ }^{10}$

Mengkonsumsi minyak goreng yang digunakan berulang-ulang (lebih dari 4 kali) yang telah mengalami oksidasi (reaksi dengan udara) dapat menyebabkan iritasi saluran pencernaan, diare, dan kanker. Selain itu minyak goreng akan mengalami ketengikan sehingga merusak tekstur dan cita rasa bahan makanan yang digoreng. ${ }^{11}$ Berdasarkan hal tersebut maka penulis tertarik untuk melakukan penelitian mengenai pengaruh frekuensi penggorengan terhadap peningkatan bilangan peroksida pada minyak goreng curah dan minyak goreng fortifikasi vitamin $\mathrm{A}$. 


\section{Metode Penelitian}

Jenis penelitian yang digunakan adalah experimental research dengan menggunakan rancangan quasi experimental. Objek penelitian ini adalah dua jenis minyak goreng yaitu minyak goreng curah dan minyak goreng fortifikasi vitamin A yang dibeli dari produsen di salah satu pasar tradisional di Yogyakarta. Analisis data yang digunakan yaitu kruskall-wallis dan dilanjutkan dengan uji Post-Hoc dengan uji Mannwhitney. Objek penelitian ini adalah dua jenis minyak goreng yaitu minyak goreng curah dan minyak goreng fortifikasi vitamin A.

Penelitian ini dilakukan di salah satu rumah di jalan Kaliurang dan pemeriksaan sampel dilakukan di Laboratorium Fakultas Kesehatan Masyarakat Universitas Ahmad Dahlan Yogyakarta. Penggorengan dilakukan sebanyak empat kali, yaitu penggorengan ke 1, 2, 3, 4 dengan tiga kali pengulangan. Hal ini dikarenakan berdasarkan survei yang telah dilakukan $90 \%$ rumah tangga melakukan penggorengan sebanyak 4-8 kali per hari. Penentuan bilangan peroksida dengan metode iodometri. ${ }^{10}$

\section{Hasil Penelitian dan Pembahasan}

\section{A. Hasil Penelitian}

Hasil penelitian tentang peningkatan bilangan peroksida dapat dilihat padatabel berikut ini:

Tabel 1. Hasil Pengukuran Peningkatan Bilangan Peroksida Tahun 2014

\begin{tabular}{lcccccc}
\hline \multirow{2}{*}{$\begin{array}{c}\text { Jenis } \\
\text { Minyak } \\
\text { Goreng }\end{array}$} & \multirow{2}{*}{ Pengulangan } & \multicolumn{5}{c}{ Frekuensi Penggorengan } \\
\cline { 3 - 6 } & & 0 & \multicolumn{4}{c}{ Bilangan Peroksida (Mek $\left.\mathrm{O}_{2} / \mathrm{Kg}\right)$} \\
\cline { 3 - 6 } Curah & 1 & 6,66 & 12,48 & 14,99 & 15,00 & 20,79 \\
& 2 & 4,16 & 12,49 & 15,00 & 16,66 & 18,31 \\
Rata-rata & 3 & 4,99 & 12,47 & 14,97 & 16,67 & 17,47 \\
Fortifikasi & 1 & 5,27 & 12,48 & 14,98 & 16,11 & 18,85 \\
Vitamin A & 2 & 0,83 & 11,65 & 11,66 & 14,15 & 16,64 \\
Rata-rata & 3 & 0,83 & 10,00 & 11,64 & 11,67 & 16,66 \\
Ryyyyy & & 0,83 & 9,99 & 12,47 & 12,51 & 19,15 \\
& & 0,83 & 10,54 & 11,92 & 12,77 & 17,48 \\
\hline
\end{tabular}

Hasil pengukuran menunjukkan ada peningkatan bilangan peroksida pada minyak goreng curah dan minyak goreng fortifikasi vitamin A. Berdasarkan Tabel 1 diketahui bahwa terjadi peningkatan bilangan peroksida setiap penambahan frekuensi penggorengan baik pada minyak goreng curah maupun minyak goreng fortifikasi vitamin A. Minyak goreng curah mempunyai rata-rata bilangan peroksida lebih tinggi dibandingkan dengan minyak goreng fortifikasi vitamin A.

Pengaruh frekuensi penggorengan terhadap kenaikan bilangan peroksida dapat dilihat pada tabel berikut ini:

Tabel 2. Hasil uji kruskal-wallis untuk menguji pengaruh frekuensi penggorengan terhadap peningkatan bilangan peroksida pada minyak goreng curah tahun 2014

\begin{tabular}{ccccc}
\hline & $\begin{array}{c}\text { Frekuensi } \\
\text { penggorengan }\end{array}$ & $\mathrm{n}$ & $\begin{array}{c}\text { Median } \\
\text { (minimum-maksimum) }\end{array}$ & $p$ \\
\hline Bilangan & 0 & 3 & $4,99(4,16-6,66)$ & \\
Peroksida & 1 & 3 & $12,48(12,47-12,49)$ & \\
minyak goreng & 2 & 3 & $14,99(14,97-15,00)$ & $<0,010$ \\
curah & 3 & 3 & $16,66(15,00-16,67)$ & \\
\hline
\end{tabular}


Berdasarkan hasil uji kruskal-wallis, diperoleh nilai p value 0,010, artinya ada pengaruh frekuensi penggorengan terhadap peningkatan bilangan peroksida pada minyak goreng curah. Untuk mengetahui kelompok mana yang mempunyai pengaruh, maka dilakukan analisis Post Hoc dengan menggunakan uji Mann-whitney.

Tabel 3. Data hasil uji Post-Hoc dengan uji Mann-whitney

\begin{tabular}{ccccc}
\hline No & Frekuensi Penggorengan & Signifikansi & Keterangan \\
\hline 1 & 0 & 1 & 0,050 & Signifikan \\
2 & 0 & 2 & 0,050 & Signifikan \\
3 & 0 & 3 & 0,050 & Signifikan \\
4 & 0 & 4 & 0,050 & Signifikan \\
5 & 1 & 2 & 0,050 & Signifikan \\
6 & 1 & 3 & 0,050 & Signifikan \\
7 & 1 & 4 & 0,050 & Signifikan \\
8 & 2 & 3 & 0,077 & Tidak Signifikan \\
9 & 2 & 4 & 0,050 & Signifikan \\
10 & 3 & 4 & 0,050 & Signifikan \\
\hline
\end{tabular}

Berdasarkan uji Post Hoc diketahui bahwa ada pengaruh frekuensi penggorengan terhadap peningkatan bilangan peroksida pada seluruh frekuensi penggorengan ( $p$ value 0,05 ) kecuali antara penggorengan kedua dan penggorengan ketiga ( $p$ value 0,077 ).

Pengaruh frekuensi penggorengan terhadap kenaikan bilangan peroksida dapat dilihat pada tabel berikut ini:

Tabel 4. Hasil uji kruskal-wallis untuk menguji pengaruh frekuensi penggorengan terhadap peningkatan bilangan peroksida pada minyak goreng fortifikasi vitamin A tahun 2014

\begin{tabular}{ccccc}
\hline & $\begin{array}{c}\text { Frekuensi } \\
\text { penggorengan }\end{array}$ & $\mathrm{n}$ & $\begin{array}{c}\text { Median } \\
\text { (minimum-maksimum) }\end{array}$ & $p$ \\
\hline Bilangan Peroksida & 1 & 3 & $10,00(9,99-11,65)$ & \\
minyak goreng & 2 & 3 & $11,66(11,64-12,47)$ & $<0,011$ \\
Fortifikasi Vit. A & 3 & 3 & $12,51(11,67-14,15)$ & \\
\hline
\end{tabular}

Berdasarkan hasil uji kruskal-wallis, diperoleh nilai p value 0,011, artinya ada pengaruh frekuensi penggorengan terhadap peningkatan bilangan peroksida pada minyak goreng fortifikasi vitamin A. Untuk mengetahui kelompok mana yang mempunyai pengaruh, maka dilakukan analisis Post Hoc dengan menggunakan uji Mann-whitney.

Tabel 5. Data hasil uji Post-Hoc dengan uji Mann-whitney

\begin{tabular}{ccccc}
\hline No & Frekuensi Penggorengan & Signifikansi & Keterangan \\
\hline 1 & 0 & 1 & 0,037 & Signifikan \\
2 & 0 & 2 & 0,037 & Signifikan \\
3 & 0 & 3 & 0,037 & Signifikan \\
4 & 0 & 4 & 0,037 & Signifikan \\
5 & 1 & 2 & 0,127 & Tidak Signifikan \\
6 & 1 & 3 & 0,050 & Signifikan \\
7 & 1 & 4 & 0,050 & Signifikan \\
8 & 2 & 3 & 0,127 & Tidak Signifikan \\
9 & 2 & 4 & 0,050 & Signifikan \\
10 & 3 & 4 & 0,050 & Signifikan \\
\hline
\end{tabular}


Berdasarkan uji Post Hoc diketahui bahwa ada pengaruh frekuensi penggorengan terhadap peningkatan bilangan peroksida pada seluruh frekuensi penggorengan kecuali antara penggorengan pertama ke penggorengan kedua ( $p$ value 0,127 ) dan penggorengan kedua ke penggorengan ketiga ( $p$ value 0,077 ).

Tabel 6. Hasil uji mann-whitney untuk mengukur peroksida pada minyak goreng curah minyak goreng fortifikasi vitamin A tahun 2014

\begin{tabular}{cccc}
\hline & $\mathrm{n}$ & $\begin{array}{c}\text { Median (minimum- } \\
\text { maksimum) }\end{array}$ & $\mathrm{p}$ \\
\hline $\begin{array}{c}\text { Bilangan Peroksida minyak goreng curah } \\
\text { Bilangan Peroksida minyak goreng } \\
\begin{array}{c}\text { fortifikasi vit. A } \\
\hline\end{array}\end{array}$ & 15 & $14,99(4,16-20,79)$ & \\
\hline
\end{tabular}

Berdasarkan hasil uji mann-whitney, diperoleh nilai $p$ value 0,65 , artinya tidak ada perbedaan bilangan peroksida pada minyak goreng curah dengan minyak goreng fortifikasi vitamin A.

\section{B. Pembahasan}

Penggorengan yang berulang-ulang menyebabkan peningkatan kandungan bilangan peroksida yang dapat meningkatkan resiko iritasi saluran pencernaan, diare, dan kanker. Selain itu minyak goreng akan mengalami ketengikan sehingga merusak tekstur dan cita rasa bahan makanan yang digoreng. ${ }^{11}$ Minyak goreng yang memiliki kandungan peroksida yang melebihi standar cenderung memiliki ciri-ciri khas yang dapat diamati dengan mata. Ciriciri tersebut diataranya berwarna coklat sampai kehitaman, memiliki endapan relatif tebal, keruh, berbuih, dan lebih kental apabila dibandngkan dengan minyak goreng dengan kadar perksida lebih rendah. ${ }^{12}$

Dalam penelitian ini lebih khusus meneliti tentang minyak curah yang banyak dikonsumsi sebagian masyarakat dibandingakan dengan minyak goreng diperkaya (fortifikasi vitamin A) yang diunggulkan kelebihannya pada setiap promosi produk. Hasil penelitian adalah sebagai berikut:

\section{Pengaruh frekuensi penggorengan terhadap peningkatan bilangan peroksida pada minyak goreng curah}

Berdasarkan hasil pengukuran dapat diketahui bahwa rata-rata bilangan peroksida pada minyak goreng curah terendah adalah pada penggorengan ke nol sebesar 5,27 $\mathrm{Mek}_{2} / \mathrm{Kg}$ dan rata-rata bilangan peroksida tertinggi adalah penggorengan keempat sebesar $18,85 \mathrm{Mek}_{2} / \mathrm{Kg}$. Bilangan peroksida pada minyak goreng curah terus meningkat dengan bertambahnya frekuensi penggorengan yang dilakukan. Bilangan peroksida pada penggorengan ke nol mencapai 5,27 Mek $\mathrm{O}_{2} / \mathrm{Kg}$, ini berarti telah terdapat bilangan peroksida sebelum dilakukan penggorengan yang mana kadarnya telah mencapai separuh dari kadar maksimal yang telah ditetapkan oleh SNI 3741:2013 dimana kadar maksimal bilangan peroksida adalah 10 Mek $\mathrm{O}_{2} / \mathrm{Kg}$, sehingga pada pengorengan yang selanjutnya bilangan peroksida terus meningkat. Bilangan peroksida pada penggorengan ke nol dapat mencapai 5,27 Mek $\mathrm{O}_{2} / \mathrm{Kg}$ karena minyak tersebut tidak disimpan dalam kemasan khusus sehingga dapat mempercepat reaksi oksidasi. Hasil penelitian ini sesuai dengan penelitian ${ }^{12}$ yang menyatakan bahwa semakin sering minyak goreng digunakan untuk menggoreng, maka bilangan peroksidanya semakin meningkat. 
Uji kruskal-wallis menunjukkan ada pengaruh frekuensi penggorengan terhadap peningkatan bilangan peroksida pada minyak goreng curah ( $p$ value $0,010)$. Hasil penelitian ini sesuai dengan penelitian ${ }^{14}$ yang menyatakan bahwa pengulangan penggorengan berpengaruh nyata terhadap bilangan peroksida. Karena pada uji kruskal-wallis Ha diterima maka dilanjutkan dengan Post Hoc menggunakan uji Mann whitney.

Hasil uji Post Hoc menunjukkan bahwa seluruh frekuensi penggorengan berpengaruh terhadap peningkatan bilangan peroksida ( $p$ value 0,050 ) nilai tersebut merupakan hasil dari seluruh frekuensi penggorengan kecuali pada penggorengan kedua dan penggorengan ketiga ( $p$ value 0,077 ) sehingga ada pengaruh seluruh frekuensi penggorengan terhadap bilangan peroksida. Hal ini dapat terjadi karena setiap proses penggorengan dapat meningkatkan oksidasi antara minyak dan udara baik melalui proses pembalikan pada saat penggorengan maupun pada saat pendinginan minyak. Hasil ini sesuai dengan hasil penelitian ${ }^{5}$ yang menyatakan bahwa semua frekuensi penggorengan memiliki perbedaan yang signifikan terhadap bilangan peroksida. Seiring dengan frekuensi dan lamanya penggorengan, minyak akan teroksidasi dan membentuk senyawa peroksida, terlihat dengan meningkatnya bilangan peroksida. ${ }^{15}$ Hal ini disebabkan oleh adanya proses kenaikan suhu pada saat pemanasan minyak disetiap penggorengan dan penurunan suhu pada saat jeda waktu antar penggorengan. ${ }^{16}$

\section{Pengaruh frekuensi penggorengan terhadap peningkatan bilangan peroksida pada minyak goreng fortifikasi vitamin A}

Berdasarkan hasil pengukuran dapat diketahui bahwa rata-rata bilangan peroksida pada minyak goreng fortifikasi vitamin $A$ terendah pada penggorengan ke nol sebesar 0,83 Mek $\mathrm{O}_{2} / \mathrm{Kg}$ dan rata-rata bilangan peroksida tertinggi adalah penggorengan keempat sebesar $17,48 \mathrm{Mek}_{2} / \mathrm{Kg}$. Hasil pengukuran bilangan peroksida yang dihubungkan dengan frekuensi penggorengan adalah bilangan peroksida pada minyak goreng fortifikasi vitamin A akan meningkat dengan bertambahnya frekuensi penggorengan. Pada minyak goreng fortitifikasi bilangan peroksida pada penggorengan ke nol adalah 0,83 Mek $\mathrm{O}_{2} / \mathrm{Kg}$. Kadar ini merupakan kadar aman karena jauh dari maksimal kadar bilangan peroksida yang ditetapkan SNI 3741:2013 yaitu 10 Mek $\mathrm{O}_{2} / \mathrm{Kg}$, hal ini karena minyak goreng fortifikasi vitamin $\mathrm{A}$ merupakan minyak goreng bermerek dimana dikemas dengan kemasan yang khusus dan diletakkan dari tempat yang terlindung dari sinar matahari. Namun, pada penggorengan kedua kadar bilangan peroksida meningkat hingga 11,92 Mek $\mathrm{O}_{2} / \mathrm{Kg}$. Hal ini dapat dipengaruhi dari bahan pangan yang digunakan untuk menggoreng, yaitu tahu yang memiliki kadar air yang tinggi sehingga minyak mengalami hidrolisis yang dapat meningkatkan bilangan peroksida. Seiring dengan frekuensi dan lamanya penggorengan, minyak akan teroksidasi dan membentuk senyawa peroksida, terlihat dengan meningkatnya bilangan peroksida. ${ }^{15}$ Ketengikan dapat terjadi karena proses oksidasi oleh oksigen udara terhadap asam lemak tidak jenuh dalam lemak. Proses oksidasi dapat terjadi pada suhu kamar, dan selama proses pengolahan menggunakan suhu tinggi. Hasil oksidasi lemak dalam bahan pangan tidak hanya mengakibatkan rasa dan bau tidak enak, tetapi juga dapat menurunkan nilai gizi, karena kerusakan vitamin dan asam lemak esensial lemak. ${ }^{10}$

Uji kruskal-wallis menunjukkan bahwa terdapat pengaruh frekuensi penggorengan terhadap bilangan peroksida ( $p$ value 0,011 ) Karena pada uji kruskal-wallis $\mathrm{Ha}$ diterima maka dilanjutkan dengan Hasil uji Post Hoc 
menggunakan uji mann whitney menunjukkan semua frekuensi penggorengan berpengaruh terhadap peningkatan bilangan peroksida kecuali pada penggorengan pertama ke penggorengan kedua dan penggorengan kedua ke penggorengan ketiga ( $p$ value 0,127 ). Hal ini karena kadar bilangan peroksida pada frekuensi penggorengan pertama dan kedua serta kedua dan ketiga hanya terjadi kenaikan yang kecil dibandingkan dengan frekuensi penggorengan yang lainnya. Hasil tersebut kemungkinan bisa disebabkan karena kadar oksigen di udara saat penelitian relatif sama. Kenaikan bilangan oksidasi karena bersentuhan langsung dengan udara yang mengandung oksigen.

Dalam proses menggoreng, oksigen merupakan faktor utama penyebab kerusakan minyak goreng. Dalam proses penggorengan kontak antara udara dengan minyak sulit dihindarkan. Udara akan mempercepat proses oksidasi dan kerusakan karena oksidasi mempunyai pengaruh paling besar terhadap perubahan cita rasa dan bau. Hal tersebut sesuai dengan penelitian Aisyah dkk. bahwa proses pemanasan meningkatkan proses oksidasi. $^{13}$

Pada cara menggoreng biasa tidak banyak vitamin A yang hilang. ${ }^{17}$ Jumlah vitamin A dalam minyak goreng akan semakin berkurang dengan bertambahnya frekuensi penggorengan. Penggunaan minyak goreng fortifikasi vitamin A sebagai media penggorengan makanan akan menyebabkan peresapan vitamin A ke dalam bahan pangan yang digoreng. ${ }^{18}$

\section{Perbedaan bilangan peroksida antara minyak goreng curah dan minyak goreng fortifikasi vitamin A}

Berdasarkan hasil pengukuran bilangan peroksida pada minyak goreng curah dan minyak goreng fortifikasi vitamin A didapatkan hasil bahwa bilangan peroksida minyak goreng curah lebih tinggi dibandingkan peningkatan bilangan peroksida minyak goreng fortifikasi vitamin $A$. Perbedaan rata-rata bilangan peroksida pada minyak goreng curah dan minyak goreng fortifikasi vitamin A dapat disebabkan oleh keterpaparan awal minyak goreng terhadap oksigen. Hal ini sesuai dengan penelitian ${ }^{14}$ yang menyatakan bahwa minyak goreng curah dijual tanpa menggunakan kemasan khusus, sehingga besar kemungkinan minyak goreng tersebut sering terpapar dengan oksigen. Keterpaparan antara minyak goreng dengan oksigen dapat mempercepat meningkatnya bilangan peroksida pada minyak goreng. Bilangan peroksida yang tinggi mengindikasikan lemak atau minyak sudah mengalami oksidasi, namun pada angka yang lebih rendah bukan selalu berarti menunjukkan kondisi oksidasi yang masih dini.

Uji mann-whitney menunjukkan tidak ada perbedaan bilangan peroksida antara minyak goreng curah dan minyak goreng fortifikasi vitamin ( $p$ value 0,065 ). Hal ini disebabkan karena peningkatan bilangan peroksida pada minyak goreng curah dan minyak goreng fortifikasi vitami A tidak berbeda jauh. Berdasarkan hasil pengukuran dapat diketahui bahwa bilangan peroksida pada minyak goreng curah dan minyak goreng fortifikasi vitamin A setelah penggorengan tidak begitu jauh berbeda. Hal tersebut disebabkan oleh kadar air yang terkandung dalam bahan pangan yang digoreng. Bahan pangan yang digunakan untuk menggoreng dapat mempengaruhi peningkatan bilangan peroksida. Pada penelitian ini, bahan pangan yang digunakan untuk menggoreng adalah tahu karena berdasarkan hasil survei tahu merupakan bahan pangan yang digunakan oleh seluruh rumah tangga. Kandungan air yang terdapat menyebabkan terjadinya hidrolisis yang dapat meningkatkan

Pengaruh Frekuensi Penggorengan terhadap Peningkatan Peroksida ..... (Wahyu Siswanto) 
bilangan peroksida. Kemungkinan yang lain karena adanya kandungan air menurunkan suhu selama penggorengan.

$\mathrm{Hal}$ tersebut sesuai dengan penelitian ${ }^{19}$ menyatakan bahwa jenis gorengan mempengaruhi bilangan peroksida, dan pengulangan penggorengan akan mempengaruhi nilai bilangan peroksida minyak. Penelitian tersebut menyatakan peningkatan bilangan peroksida terbesar adalah minyak yang dipakai untuk menggoreng tahu kemudian tempe dan pisang. Hal ini dapat disebabkan oleh tingginya kadar air yang terkandung dalam tahu.Adanya air menyebabkan lemak dapat terhidrolisis menjadi gliserol dan asam lemak. Reaksi ini dipercepat oleh basa, asam, dan enzimenzim. Dalam teknologi makanan, hidrolisis oleh enzim lipase sangat penting karena enzim tersebut terdapat terdapat pada semua jaringan yang mengandung minyak. Dengan adanya lipase, lemak akan diuraikan sehingga kadar asam lemak bebas lebih dari $10 \%$.

Dengan penggorengan yang berulang akan menyebabkan kerusakan minyak goreng yang ditunjukkan dengan peningkatan bilangan peroksida. Semakin banyak penggorengan yang dilakukan pada minyak goreng atau semakin tinggi suhunya akan meningkatkan bilangan peroksida. Hidrolisis sangat menurunkan mutu minyak goreng. Minyak yang telah terhidrolisis, smoke point-nya menurun, bahan-bahan menjadi coklat dan lebih banyak menyerap minyak. ${ }^{20}$

Saat proses menggoreng, disarankan untuk menggunakan api sedang $\left(<200^{\circ} \mathrm{C}\right)$. Minyak goreng yang digunakan sebaiknya tidak melebihi dua kali pengulangan sehingga tidak terbentuk adanya asam lemak trans pada makanan yang digoreng. Pada suhu lebih dari $100^{\circ} \mathrm{C}$, asam lemak jenuh pada minyak akan teroksidasi. ${ }^{21}$ Suhu yang tinggi selama penggorengan akan mempercepat proses oksidasi pada minyak, dan proses oksidasi akan menurun apabila suhu turun. ${ }^{22}$

\section{SIMPULAN DAN SARAN}

\section{A. Simpulan}

Ada pengaruh frekuensi penggorengan terhadap peningkatan bilangan peroksida pada minyak goreng curah dan minyak goreng fortifikasi vitamin.

\section{B. Saran}

a. Masyarakat agar berhati-hati dalam memilih minyak goreng yang akan digunakan untuk menggoreng, terutama dalam memilih minyak goreng curah.

b. Sebaiknya minyak goreng dipakai untuk menggoreng maksimal tiga kali.

\section{Daftar Pustaka}

1. Badan Perijinan dan Penanaman Modal Daerah Provinsi Kalimantan Timu, Investasi Industri Minyak Goreng Kelapa Sawit, Kalimantan Timur, 2009.

2. Anonim, Persaingam Produk Licinnya Bisnis Minyak Branded, 2006, www.suarakaryaonline.com, diambil 15 Desember 2013 di Yogyakarta.

3. Fadhilla, AR., Analisis Kepuasan dan Loyalitas Konsumen Minyak Goreng Kemasan Merek Bimoli (Kasus: Rumah Tangga Di Kota Bogor), Skripsi, Fakultas Pertanian IPB, Bogor, 2008.

4. Eugenia, I., Top Brand Dalam Pasar Komoditi Bermerek, 2012, www.topbrand-award.com, diambil 15 April 2013 di Yogyakarta. 
5. Chandra, Brand Diagnostic dan Hasil Pengukuran Top Brand Index - Analisis Pada Industri Asuransi Jiwa, 2012,www.topbrand-award.com/, diambil 15 April 2013, Yogyakarta.

6. Anna, LK, Minyak Goreng Diperkuat dengan Vitamin A, 2011,http://health.kompas.com, diambil 8 Januari 2014, Yogyakarta.

7. Prasetyo, U., Fortifikasi Vitamin A: Beban Baru Industri Minyak Goreng, Majalah Elais Indonesia, pp. 23-25, 2013.

8. Indah, RSY, Pengaruh Frekuensi Penggorengan, Cara Penimpanan Dan Lama Penyimpanan Minyak Goreng Terhadap Angak Peroksida Dan Angka Asam, Skripsi, FK UGM, Yogyakarta, 2008.

9. Muchtadi, TR., Sugiyono, Ayustaningwarno, F., Ilmu Pengetahuan Bahan Pangan, Alfabeta, Bogor, 2010.

10. Ketaren, S., Minyak dan Lemak Pangan, UI Press, Jakarta, pp. 1, 24, 33, 64, 99-100, 140, 184, 191, 2008.

11. Khomsan, A., Pangan dan Gizi Untuk Kesehatan, Rajawali Sport, Jakarta, 2010.

12. Mulasari, S.A., Utami, R, R., Kandungan Peroksida Pada Minyak Goreng Pedagang Makanan Gorengan Sepanjang Jalan Prof. Dr. Soepomo Umbulharjo Yogyakarta Tahun 2012,Jurnal Archive of Community Health, Vol/No: 1(2), pp. 120-123, 2012.

13. Aisyah, Yulianti, dan Fasya, Penurunan Angka Peroksida dan Asam Lemak Bebas (FFA) Pada Proses Bleaching Minyak Goreng Bekas Oleh Karbon Aktif Polong Buah Kelor (Moringa Oliefera. Lamk) Dengan Aktivasi NaCl, Jurnal ALCHEMY, Vol/No: 1(2), pp. 53103, 2010.

14. Aminah, S., Bilangan Peroksida Minyak Goreng Curah dan Sifat Organoleptik Tempe pada Pengulangan Penggorengan, Jurnal Pangan dan Gizi, Vol/No: 01(01), pp. 7-14, 2010.

15. Ayu, D, F., Hamzah, F, H., Evaluasi Sifat Fisio-Kimia Minyak Goreng yang Digunakan oleh Pedagang Makanan Jajanan di Kecamatan Tampan Kota Pekanbaru, Sagu, Vol/No: 9(1), pp. 4-14, 2010.

16. Martianto, D., Marliyati, S, A., Arafah, A, A., Retensi Vitamin A pada Minyak Goreng Curah yang Difortifikasi Vitamin A dan Produk Gorengannya, J. Teknol. dan Industri Pangan, No. 2, pp. 83-89, 2009.

17. Almatsier, S., Prinsip Dasar Ilmu Gizi, Gramedia Pustaka Utama, Jakarta, 2004.

18. Khomsan, A., Pangan dan Gizi Untuk Kesehatan, Rajawali Sport, Jakarta, 2010.

19. Abdullah, Pengaruh Gorengan Dan Intensitas Penggorengan Terhadap Kualitas Minyak Goreng, J. Pilar Sains, Vol/No: 6(2), pp. 1-6, 2007.

20. Winarno, F,G., Kimia Pangan Dan Gizi, PT. Gramedia Pustaka Utama, Jakarta, 2004.

21. Sartika, Pengaruh suhu dan Lama Proses Menggoreng (Deep Frying) Terhadap Pembentukan Asam Lemak Trans, Jurnal MAKARA, SAINS,Vol/No: 13(1), pp. 23-28, 2009.

22. Tarigan, Nurhayati., Oppusunggu, Pengaruh Penyuluhan Kepada Pedagang Gorengan dengan Angaka Peroksida dan Asam pada Minyak Goreng, Jurnal Ilmiah PANNMED,Vol/No: 2(1), pp. 20-28, 2007. 
